\title{
MICROBIOLOGICAL CHARACTERIZATION OF STABLE RESUSPENDED DUST
}

\section{NORA KOVÁTS ${ }^{1}$, ESZTER HORVÁTH ${ }^{1}$, BEATRIX JANCSEK-TURÓCZI ${ }^{1}$, ANDRÁS HOFFER ${ }^{2}$, ANDRÁS GELENCSÉR ${ }^{1}$, PÉTER URBÁN ${ }^{3}$, ÍRISZ E. KISS ${ }^{3}$, ZOLTÁN BIHARI ${ }^{3,4}$, and CSABA FEKETE ${ }^{4}$}

\author{
${ }^{1}$ University of Pannonia, Veszprém, Hungary \\ Institute of Environmental Sciences \\ ${ }^{2}$ Air Chemistry Group of the Hungarian Academy of Science, Veszprém, Hungary \\ ${ }^{3}$ University of Pécs, Pécs, Hungary \\ Szentágothai Research Centre \\ ${ }^{4}$ Bay Zoltán Nonprofit Ltd. (BAY-BIO), Szeged, Hungary
}

\begin{abstract}
Objectives: Air quality in the stables is characterized by elevated level of dust and aeroallergens which are supposed to directly cause or exacerbate several respiratory disorders. The most often recognized problem is recurrent airway obstruction (RAO), previously known as chronic obstructive pulmonary disease (COPD). There is some indication that aeroallergens (among them endotoxins) may also cause inflammation in human airways and may exceed safe levels in stables. Monitoring studies have covered mainly the determination of the concentration of respirable particles and of culturable fungi and their toxins. However, these particles do not only directly affect the respiratory system, but might act as a carrier conveying toxic contaminants and biological agents such as bacteria. In a typical, 20-horse Hungarian stable, microbial community of respirable fraction of resuspended dust has been characterized to reveal if these particles convey hazardous pathogenic bacteria, posing risk to either horses or staff. Material and Methods: Resuspended dust was sampled using a mobile instrument. The instrument contains a PARTISOL-FRM model 2000 sampler that was operated at a flow rate of $16.7 \mathrm{l} / \mathrm{min}$ and a cyclone separator which collected the particulate matter with an aerodynamic size between $1 \mu \mathrm{m}$ and $10 \mu \mathrm{m}\left(\mathrm{PM}_{1-10}\right)$ fraction. Microbial taxa were identified by culture-independent next generation sequencing (NGS) of variable $16 \mathrm{~S}$ ribosomal ribonucleic acid (rRNA) gene regions. Results: In total, 1491 different taxa were identified, of them 384 were identified to species level, 961 to genus level. The sample was dominated by common ubiquitous soil and organic material-dwelling taxa. Conclusions: Pathogens occurred at low abundance, and were represented by mostly facultative human pathogens, with the prevalence of Staphylococcus species.
\end{abstract}

Key words:

Stable, Air quality, Dust, Microbial community, Next generation sequencing, Pathogens

Financial support by: Hungarian Research Fund OTKA K 101484 and TÁMOP-4.2.2.A-11/1/KONV-2012-0064 research program supported by the European Union and co-financed by the European Social Fund. Beneficiary: University of Pannonia. Program manager: András Gelencsér, Ph.D.

Received: February 3, 2015. Accepted: May 29, 2015.

Corresponding author: N. Kováts, University of Pannonia, Institute of Environmental Sciences, Egyetem 10, 8200 Veszprém, Hungary, (e-mail: kovats@almos.unipannon.hu). 


\section{INTRODUCTION}

Air quality in the stables is characterized by elevated level of dust and aeroallergens which are supposed to directly cause or exacerbate several equine respiratory disorders. The most often recognized problem is recurrent airway obstruction (RAO), previously known as chronic obstructive pulmonary disease (COPD) [1]. Recurrent airway obstruction is supposed to develop due to hypersensitivity to environmental allergens, principally those associated with stabling, resulting in inflammation and reversible obstruction of the lower airway.

As such, most studies have focused on respirable particle monitoring and determining the presence of aeroallergens. Particle monitoring techniques are reviewed by Millerick-May et al., 2011 [2]. There is some indication that aeroallergens (among them endotoxins) may also cause inflammation in human airways and may exceed safe levels in stables [3,4].

In general, there are 2 important sources contributing to airborne dust, feed and bedding. Of feed, hay has the highest contribution [5]. Clements and Pirie [6] found that feed had a greater influence on mean and maximum respirable dust concentration than bedding.

Apart from the direct effect airborne dust has on the respiratory system, these particles might act as a carrier conveying toxic contaminants and biological contaminating agents such as microorganisms [7]. In stables, for identification of microbial community being found on airborne particles, most often culture techniques are applied [4]. Though not specifically in stables, most recent studies use culture-independent methods such as real-time polymerase chain reaction (PCR) technique [8,9] or ribonucleic acid (RNA) gene sequencing [10,11].

In our study, microbial community of respirable fraction of resuspended dust was sampled in a typical, 20-horse Hungarian stable and microbial community was characterized by culture-independent next generation sequencing (NGS) of variable $16 \mathrm{~S}$ ribosomal ribonucleic acid (rRNA) gene regions. Besides, giving a general description of the microbial community being found on respirable particles, the main target of the work was to reveal if these particles convey hazardous pathogenic bacteria, posing risk to either horses or staff.

\section{MATERIAL AND METHODS \\ Sampling}

The studied stable was an enclosed 20-stall building. Along a central aisle, 10-10 boxes are placed, with doors providing ventilation. Horses are kept in the pasture during the day whenever weather permits. During sampling, the horses were also kept in the pasture.

For sampling, a specific mobile sampling unit was used, which was developed to simulate the effects of traffic and wind conditions on road surfaces and collect the respirable fraction of resuspended road dust $\left(\mathrm{PM}_{10}\right)$ [12]. The instrument uses a leaf blower to mobilize dust from paved surfaces, simulating very windy conditions (wind speeds $\sim 65 \mathrm{~km} / \mathrm{h}$ ). The key unit in the apparatus is a PARTISOL-FRM model 2000 sampler that is operated at a flow rate of $16.7 \mathrm{l} / \mathrm{min}$ and contains a cyclone separator which collects the $\mathrm{PM}_{1-10}$ fraction (particles with aerodynamically equivalent diameters $1 \mu \mathrm{m}$ and $10 \mu \mathrm{m}$ ) in bulk; the collected material is then transferred into pre-weighted cleaned vials. The sampler is mounted on a mobile platform and powered with a portable electrical power generator. Sampling was completed on 9 March 2013.

\section{Deoxyribonucleic acid (DNA) extraction and PCR amplification}

Deoxyribonucleic acid concentration was determined using the Qubit dsDNA HS Assay Kit with the Qubit 2.0 Fluorometer according to the manufacturer's (Life Technologies) instructions.

For fusion method-based, unidirectional Ion Torrent bacterial 16S rRNA sequencing, PCR amplification was carried 
out, using the forward primer consisting of the Ion Torrent adapter region (trP1: 5'-CCTCTCTATGGGCAGTCGGTGAT-3') fused to the 5' end of 16S rDNA target sequence (Bakt_341F: 5'-CCTACGGGNGGCWGCAG-3'). In reverse primers, Ion A adapter region (5'-CCATCTCATCCCTGCGTGTCTCCGACTCAG-3') was linked downstream to the sample identifying Ion Xpress Barcode (Life Technologies) sequence, which was fused to the 5' end of the $16 \mathrm{~S}$ rDNA target sequence (Bakt_805R: 5'-GACTACHVGGGTATCTAATCC-3').

Triplicate reactions were carried out in $20 \mu \mathrm{l}$ volumes using KOD Hot Start DNA Polymerase (Novagen) according to the manufacturer's instructions, except that $10 \mathrm{ng}$ of template gDNA and 3\% dimethyl sulfoxide (DMSO) were present in all reactions. Cycling conditions involved an initial 2-min denaturing step at $95^{\circ} \mathrm{C}$, followed by $25 \mathrm{cy}$ cles of $30 \mathrm{~s}$ at $95^{\circ} \mathrm{C}, 30 \mathrm{~s}$ at $54^{\circ} \mathrm{C}$, and $30 \mathrm{~s}$ at $70^{\circ} \mathrm{C}$ and a final elongation step of $5 \mathrm{~min}$ at $70^{\circ} \mathrm{C}$. Polymerase chain reaction products were pooled and a 2-step purification using 0.5 volumes of Agencourt AMPure XP Reagent was performed.

The quality and quantity of the ca. 530-bp products were assayed by DNA 1000 Kit on Agilent Bioanalyzer 2100 instrument. Twenty pM of total DNA were amplified in an emulsion PCR followed by target enrichment by an Ion OneTouch 400 template kit, whilst sequencing of the pooled library was performed using an Ion Torrent Personal Genome Machine (PGM) system and a 316v2 chip with the Ion Sequencing 400 kit according to the Life Technologies' protocol.

From an $80 \mathrm{~m}^{2}$ area, $39.57 \mathrm{mg} \mathrm{PM}_{1-10}$ fraction were collected. Due to the low sample quantity and the potential presence of PCR inhibitors, the determination of the effectiveness of the applied DNA extraction method was necessary. A sterile spicemen of rock was crushed in a ball-mill to $\mathrm{PM}_{1-10}$ fraction, and different quantities of Bacillus subtilis were added to $20 \mathrm{mg}$ of samples. Deoxyribonucleic acid extraction was performed, and qualities of samples were evaluated. With the slight modification of the recommended procedure, and the optimization of the dry weight/buffer rate, successful amplification of $16 \mathrm{~S}$ rRNA gene was accomplished from samples containing 20-30 cells each.

\section{Bioinformatic analyses}

In order to classify reads covering the variable regions (V3, V4) of 16S rRNA gene up to species level, the bioinformatic pipeline described by Eiler et al. [13] was slightly modified. The operating system was Ubuntu, BioLinux 7 and the open-source software MOTHUR 1.31.2, R 3.0.1, Qiime 1.7.0, Cytoscape 2.7.0 and Krona excel template were applied. Out of 1.1 million total reads, sequences having an average quality number under 25 , containing ambiguous bases, homopolymers longer than 8 bases, having more than 1 mismatch to the barcode sequence, more than 2 mismatches to the primer sequence or being shorter than $400 \mathrm{bp}$ and chimeric sequences were discarded.

The unique sequences were aligned to the appropriate reference small subunit databases (Greengenes, Ribosomal Database Project (RDP) and Silva). For operational taxonomic unit (OTU) calculations, a 97\% similarity cutoff was used, and the OTU assignment data and sequence to sample mapping were used to generate the OTU-based table to count the number of sequences per OTU per sample.

\section{RESULTS}

About $20 \%$ of the reads could be identified on the species level, $49 \%$ on the genus level and $17.5 \%$ on the class level. Among the identified bacteria, Gram-negative organisms were present at $59.4 \%$, and Gram-positive organisms at $40.1 \%$ of relative abundance. Half percent of the taxa belong to phyla known only from sequencing data, and not classified according to their cell wall structure.

The relative abundance of the most common phyla is presented in Figure 1. 


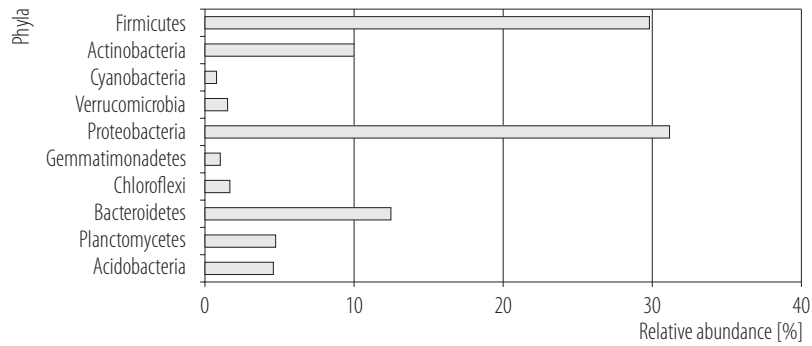

Fig. 1. Relative abundance of the most abundant phyla

\section{DISCUSSION}

In fact, the majority of the genera observed are ubiquitous soil dwelling bacteria, such as Pedobacter, with 28 species/ strains (total read count of Pedobacter species was 275, amounting to $1.934 \%$ ) or Rhizobium sp. Occurrence of pathogenic bacteria in our sample was rather low, and almost exclusively restricted to species isolated from human specimens. Staphylococcus genus was the most dominant (total read count 1064, amounting to $7.42 \%$ ). Coagulase-negative staphylococci (CoNS) are normally considered as part of the animal microbiota, inhabiting the skin, skin glands and mucous membranes of various mammals and birds [14]. Staphylococcus cells can be maintained for relatively long periods of time on various surfaces and can survive in aerosols for extended periods. Aerosol transmission of staphylococci dissemination is far under-estimated root of colonisation [15,16].

Though CoNS are generally regarded to be of low virulence, several Staphylococcus species occurring in the sample have been isolated from (human) clinical specimens: S. succinus (the most dominant species with read count 711, amounting to 4.957\%) [17]; S. equorum (read count 118 , amounting to $0.823 \%$ ) $[17,18]$. Staphylococcus xylosus (read count 14, amounting to $0.098 \%$ ) has been shown to play a role in infections of the urinary tract in humans and more rarely, in pneumonia [19]. The prevalence of Staphylococcus species is not surprising: in a study conducted in a poultry house, Staphylococcus sp., including S. lentus, S. xylosus, S. sciuri, and S. chromogenes accounted for $42 \%$ of all isolated microorganisms [20].
The pathogenicity of the abundant Streptococcus infantarius subsp. infantarius (read count 195, amounting to $1.36 \%$ of the total sample) is not clear: the species was differentiated from the Streptococcus bovis / Streptococcus equinus complex isolated from human samples and associated with non-colonic cancer [21,22].

Acinetobacter ursingii (read count 66, amounting to $0.46 \%$ of the total sample) was isolated from human clinical samples [23] and reported to cause bacteremia in a patient with a pulmonary adenocarcinoma [24].

Amongst rare bacteria (taxa represented by only 1 read count [25]), pathogens or facultative pathogens have also been identified, such as Bacillus anthracis, an (uncultured) Legionella sp. (identified only to genus level) or Aerococcus viridans which has rarely been reported to cause endocarditis or septic arthritis [26].

\section{CONCLUSIONS}

The overall objective of this study was to obtain a snapshot of the culturable microbiota of respirable fraction of stable resuspended dust using Ion Torrent sequencing of $16 \mathrm{~S}$ rRNA gene. Analysis of the microbial community of the $\mathrm{PM}_{1-10}$ fraction of resuspended dust within the stable revealed that its major components are taxa naturally present on soil particles and on organic material such as hay or straw. Somewhat against our starting hypothesis, these particles have not conveyed pathogens posing hazard to horses' health; however, some human pathogens have been identified.

\section{ACKNOWLEDGMENTS}

Special thanks go to the anonymous owner and staff who permitted sampling and provided assistance.

\section{REFERENCES}

1. Bowles KS, Beadle RE, Mouch S, Pourciau SS, LittlefieldChabaud MA, Le Blanc C, et al. A novel model for equine recurrent airway obstruction. Vet Immunol Immunopathol. 2002;87:38-9, http://dx.doi.org/10.1016/S0165-2427(02)00081-8. 
2. Millerick-May ML, Karmaus W, Derksen FJ, Berthold B, Holcombe SJ, Robinson NE. Local airborne particulate concentration is associated with visible tracheal mucus in Thoroughbred racehorses. Equine Vet J. 2013;45:85-90, http://dx.doi.org/10.1111/j.2042-3306.2012. 00568.x.

3. McGorum BC, Ellison J, Cullen RT. Total and respirable airborne dust endotoxin concentrations in three equine management systems. Equine Vet J. 1998;30:430-4, http://dx.doi. org/10.1111/j.2042-3306.1998.tb04514.x.

4. Samadi S, Wouters IM, Houben R, Jamshidifard A-R, van Eerdenburg F, Heederik DJJ. Exposure to inhalable dust, endotoxins, $\beta(1 \rightarrow 3)$-glucans, and airborne microorganisms in horse stables. Ann Occup Hyg. 2009;53(6):595-603, http://dx.doi.org/10.1093/annhyg/mep040.

5. Webster AJF, Clarke AF, Madelin TM, Wathes CM. Air hygiene in stables: Effects of stable design, ventilation and management on the concentration of respirable dust. Equine Vet J. 1987;19:448-53, http://dx.doi. org/10.1111/j.2042-3306.1987.tb02641.x.

6. Clements JM, Pirie RS. Respirable dust concentrations in equine stables. Part 1: Validation of equipment and effect of various management systems. Res Vet Sci. 2007;83:256-62, http://dx.doi.org/10.1016/j.rvsc.2006.12.002.

7. Fleming K, Hessel EF, van den Weghe HFA. Generation of airborne particles from different bedding materials used for horse keeping. J Equine Vet Sci. 2008;28(7):408-18, http:// dx.doi.org/10.1016/j.jevs.2008.05.004.

8. Fallschissel K, Kämpfer P, Jäckel U. Direct detection of Salmonella cells in the air of livestock stables by realtime PCR. Ann Occup Hyg. 2009;53(8):859-68, http:// dx.doi.org/10.1093/annhyg/mep060.

9. Kaushik R, Balasubramanian R. Assessment of bacterial pathogens in fresh rainwater and airborne particulate matter using Real-Time PCR. Atmos Environ. 2012;46:131-9, http://dx.doi.org/10.1016/j.atmosenv.2011.10.013.

10. Cho BC, Hwang CY. Prokaryotic abundance and 16S RNA gene sequences detected in marine aerosols on the East
Sea (Korea). FEMS Microbiol Ecol. 2011;76:327-41, http:// dx.doi.org/10.1111/j.1574-6941.2011.01053.x.

11. Dybwad M, Granum PE, Bruheim P, Blatny JM. Characterization of airborne bacteria at an underground subway station. Appl Environ Microbiol. 2012;78(6):1917-29, http:// dx.doi.org/10.1128/AEM.07212-11.

12. Jancsek-Turóczi B, Hoffer A, Nyírő-Kósa I, Gelencsér A. Sampling and characterization of resuspended and respirable road dust. J Aerosol Sci. 2013;65:69-76, http://dx.doi. org/10.1016/j.jaerosci.2013.07.006.

13. Eiler A, Heinrich F, Bertilsson S. Coherent dynamics and association networks among lake bacterioplankton taxa. ISME J. 2012;6(2):330-42, http://dx.doi.org/10.1038/ismej.2011.113.

14. Hauschild T. Phenotypic and genotypic identification of staphylococci isolated from wild small mammals. Syst Appl Microbiol. 2001;24:411-6, http://dx.doi.org/10.1078/07232020-00050.

15. Thompson K-A, Bennett AM, Walker JT. Aerosol survival of Staphylococcus epidermidis. J Hosp Infect. 2011;78:216-20, http://dx.doi.org/10.1016/j.jhin.2010.12.009.

16. Kloos WE. Natural populations of the genus Staphylococcus. Annu Rev Microbiol. 1980;34:559-92, http://dx.doi. org/10.1146/annurev.mi.34.100180.003015.

17. Nováková D, Sedláček I, Pantuček R, Štětina V, Švec P, Petráš P. Staphylococcus equorum and Staphylococcus succinus isolated from human clinical specimens. J Med Microbiol. 2006;55:523-8, http://dx.doi.org/10.1099/jmm.0.46246-0.

18. Bija MD, Luma HN, Mbida PA, Nguenkam CT, Ebongue CO. [Cervical spondylodiscitis due to Staphylococcus equorum]. Med Mal Infect. 2013;43:254-7, http://dx.doi. org/10.1016/j.medmal.2013.05.007. French.

19. Siqueira JF, Lima KC. Staphylococcus epidermidis and Staphylococcus xylosus in a secondary root canal infection with persistent symptoms: A case report. Aust Endod J. 2002;28: 61-3, http://dx.doi.org/10.1111/j.1747-4477.2002.tb00382.x.

20. Bródka K, Kozajda A, Buczyńska A, Szadkowska-Stańczyk I. The variability of bacterial aerosol in poultry houses depending on selected factors. Int J Occup Med Environ 
Health. 2012;25(3):281-93, http://dx.doi.org/10.2478/s13382012-0032-8.

21. Schlegel L, Grimont F, Collins MD, Régnault B, Grimont PAD, Bouvet A. Streptococcus infantarius sp. nov., Streptococcus infantarius subsp. infantarius subsp. nov. and Streptococcus infantarius subsp. coli subsp. nov., isolated from humans and food. Int J Syst Evol Microbiol. 2000;50:142534, http://dx.doi.org/10.1099/00207713-50-4-1425.

22. Jans C, Follador R, Hochstrasser M, Lacroix C, Meile L, Stevens MJA. Comparative genome analysis of Streptococcus infantarius subsp. infantarius CJ18, an African fermented camel milk isolate with adaptations to dairy environment. BMCGenomics. 2013;14:200, http://dx.doi.org/10.1186/14712164-14-200.

23. Nemec A, de Baere T, Tjernberg I, Vaneechoutte M, van der Reijden TJK, Dijkshoorn L. Acinetobacter ursingii sp. nov. and Acinetobacter schindleri sp. nov., isolated from human clinical specimens. Int J Syst Evol Microbiol. 2001;51:1891-9, http://dx.doi.org/10.1099/00207713-515-1891.

24. Loubinoux J, Mihaila-Amrouche L, le Fleche A, Pigne E, Huchon G, Grimont PAD, et al. Bacteremia caused by Acinetobacter ursingii. J Clin Microbiol. 2003;41(3):1337-8, http://dx.doi.org/10.1128/JCM.41.3.1337-1338.2003.

25. Kováts N, Horváth E, Jancsek-Turóczi B, Hoffer A, Tóth Z, Bihari Z, et al., editors. Rare airborne bacteria identified in resuspended dust in stables by next generation sequencing. Proceedings of the 1st International Conference on Atmospheric Dust; 2014 Jun 1-6; Castellaneta Marina, Italy. ProScience. 2014;1:342-7.

26. Taylor PW, Trueblood MC. Septic arthritis due to Aerococcus viridans. J Rheumatol. 1985;12(5):1004-5.

This work is available in Open Access model and licensed under a Creative Commons Attribution-NonCommercial 3.0 Poland License - http://creativecommons.org/ licenses/by-nc/3.0/pl/deed.en. 